\title{
Six Sigma Method Important Element of Sustainability
}

\author{
Ioan David Legman ${ }^{1 *}$ \\ Petruţa Blaga ${ }^{2}$ \\ ${ }^{1,2}$ University of Medicine, Pharmacy, Sciences and Technology "George Emil Palade" of Târgu-Mureş, \\ Gheorghe Marinescu 38, Târgu-Mureş, 540139, Romania
}

\begin{abstract}
Six Sigma is not a training, but it is business strategy which involves the entire staff. The main goal of this works represents the analysis of the implementation of Six Sigma method within a company, like future solution for growing and developing a business. As main method of research was used documentation. The research carried out in this work will try to test/research two important aspects regarding the situation of a company: applying these methods accordingly may produce positive effects on long term on the business environment and create a healthy growth and economic development within a company.
\end{abstract}

Key words: Six Sigma, sustainability, economic activity, economic efficiency, costs, economy, economic environment

\section{JEL Classification: D24, Q01, Q56}

(C) 2019 Publised by ACTA MARISIENSIS, SERIA OECONOMICA, Publisher University Press Târgu Mureș, issued on behalf of University of Medicine, Pharmacy, Sciences and Technology "George Emil Palade" from Tîrgu Mureș, România

\footnotetext{
* Corresponding author: Ioan David Legman

e-mail: daveione@yahoo.com
} 


\section{INTRODUCTION}

The tertiary sector as do the other sectors of national economy was quite affected by the economic crisis from 2008-2009. A big part of consumers they no longer can afford their expenses which they had before this crisis. Of course, an important element it was also reducing population incomes, which according to Keynes's Psychological Law, seems to have made a decisive contribution to reducing consumption. Within an economic cycle, regardless of whether it is a Juglar or Kitchin cycle, the contraction period which the national economy experienced around 2010 was followed by a period of expansion.

Given the evolution of the crisis at national level, most of the companies have tried to reduce costs as much as possible. This method of cost cutting has been a practice that has been used quite often over time. Throughout the year 2011 incomes continued to decline, leading to a dramatic drop in consumption. With such a wide range of services, customers are becoming less tolerable to poor quality services. Even if a company would reduce their tolerable costs, it will need to continue to provide quality services for both business sustainability and customer keeping.

To intervene in the hospitality industry without affecting the quality of services is quite difficult. The question is why in the hospitality industry there are restraint to apply the Six Sigma method.

Six Sigma is a methodology for solving problems, in other words, it is the most effective method to improve the performance of the organization.

Six Sigma is the main point in creating customer satisfaction and earning his loyalty. The method is used in organizations by people who know this element. As in the martial arts where to become an expert you must demonstrate certain skills and in the case of the Six Sigma method the applicant must demonstrate a good ability to apply knowledge. In order to become a master, the person will have to practice and apply certain principles in a practical way. All employees will have to be actively involved in the activities. The way Six Sigma identifies problems is called DMAIC, which defines, measures, analyzes, implements and controls.

Six Sigma method represent an advanced methodology of efficiency, focused on production processes (Dan, 2012).

\section{CONCEPTUAL DEVELOPMENTS OF SIX SIGMA AND LEAN SIX SIGMA IN INDUSTRY}

\subsection{Six Sigma Method}

Six Sigma does not exist 30 years ago. So Bill Smith, a renowned engineer at Motorola in Arizona (USA), in the 1980s found a correlation between product complexity, process capability and system failure. There is no business that cannot be improved with Six Sigma and Lean Six Sigma method (Nelson \& Sproull, 2016).

First of all, Six Sigma is a methodology for solving problems. Some authors say that it would actually be the most effective way to improve a business (Truscott, 2003). Six Sigma performance is the statistical term for a process that produces 3 or 4 defects out of a million possible defects. 


\section{sciendo}

ACTA MARISIENSIS, SERIA OECONOMICA

Online:ISSN 2668-3989, ISSN L 2668-3148

Print:ISSN 2668-3148, ISSN L 2668-3148

doi: $10.2478 /$ amso-2019-0003

A Six Sigma organization uses these methods to improve performance: low costs, high incomes, improving customer satisfaction and not at least minimizing the flaws. This is because high goals and performance are set. In other words, the business is taken from the comfort zone, of course for a short period and brought to a new area where changes are taking place. It can be said that Six Sigma minimizes errors and maximizes value (Bhale, 2017). Every mistake is paid, and given the statistics results for many of these companies, these errors represent a cost of $20 \%$ $-30 \%$. There is room for better in every organization.

The objectives of Six Sigma in services are to understand how certain errors occur in customer relationships, which leads to their dissatisfaction and how they can increase customer satisfaction. These methods can be applied in any organization regardless of its size. In terms of Six Sigma usage methodology, it comprises 5 stages (Gygi \& DeCarlo, 2005):

1. Definition - the phase where the problem is identified, the project is launched and the team is organized

2. Measurement - the phase in which the data that justify the purpose of applying this method is identified

3. Analysis - in this phase, the causes underlying a poor performance are identified

4. Improving - involves the use of potential care solutions for the functioning of processes

5. Control - following the performances and maintaining them

\section{Figure no. 1 - Components of the Six Sigma method}

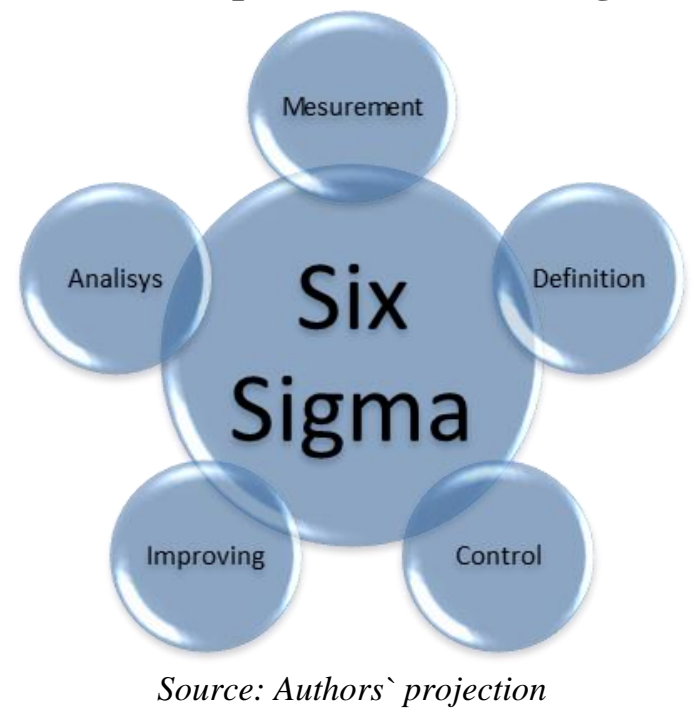

The fundamental difference between Six Sigma method and other improving programs is the ability of this method to facilitate solving problems at the firm (Tetteh \& Uzochukwu, 2015).

\subsection{Lean Six Sigma method}

Lean Six Sigma it is a concept about process change and improvement, about eliminating and reducing process variation (Kesterson, 2018). This concept was introduced in 2002by Michael George in the book Lean Sig Sigma. The introduction of this concept brought to a 
decrease in cost and an increase in profitability. When you change a process, it is almost always a matter of changing what people do and how (Bloom, 2016).

Lean philosophy is based on the creation of high quality products with the lowest costs, delivered on time. A Lean production system generates low costs with high labor productivity, in which speed is essential and of course the best quality.

Lena Six Sigma method is segmented into 4 phases (Tetteh \& Uzochukwu, 2015):

1. Planning and organizing - in this stage the schedule is organized;

2. Evaluation - the data is collected, objectives are set, evaluating team is organized;

3. Analysis - an economic and technical analysis is carried out and the implementation options;

4. Implementation - the project justification, the obtaining of funds, the installation of the equipment and the implementation of the procedures take place.

Customers are increasingly demanding products with maximum quality at a reduced price. The modern customer waits for the products to be delivered at an optimal cost. In order to attract customers and be competitive on the market, organizations should constantly find ways to reduce costs and increase productivity. Such support is this Lean Six Sigma method.

Main benefits of Lean system would be:

$\checkmark$ High quality;

$\checkmark$ High efficiency;

$\checkmark$ Resolving some problems;

$\checkmark$ Job security;

$\checkmark$ Increasing employee morale;

$\checkmark$ Improving customer relations;

$\checkmark$ Improving the response reaction;

$\checkmark$ Increasing productivity and profitability.

Of course, there are opinions that claim that Six Sigma and Lean Sigma ignore the human factor (Caroll, 2013).

\subsection{Cost reduction - an important element in the Six Sigma method}

The cost of production, representing the labor and material effort required to obtain a product, is one of the most important synthetic indicators that characterize the economic activity of a company. The notion of cost, from the etymological point of view, comes from the Latin language of the verb "constare", which means to establish, to fix. The cost should not and cannot be considered as a result of a calculation, but as an objective appearance generated by the consumption of values that caused it. Cost as a definition represents the totality of the expenses determined by the acquisition, allocation and consumption of the production factors, made by a company in order to produce and dispose of the economic goods. The production and sale of economic goods requires a certain consumption of production factors.

If we analyze the costs under the action of the physical volume of the production, we find the existence of two groups of costs: a first group whose size changes according to the change of the physical volume of the production and another group whose size remains constant against these changes.

The first group includes that part of the total costs whose character is variable with the modification of the physical volume of the production, called variable costs. In the second group is the part of the total costs that remains constant with respect to changes in the physical volume of production and forms the fixed costs. In the specialty literature the fixed costs are defined as those costs which, when changing the physical volume of the production, do not change their 
size or change it in insignificant proportions. The tendency to create total private fixed costs as a whole is influenced by the technical progress, as a result of a mechanization and automation of the production processes and other factors of care for the characterization of this process. Economic practice shows that, as a rule, a firm with a higher degree of mechanization and automation, have a higher level of fixed costs, however, or a firm with a lower degree of mechanization.

The effect of increasing the physical volume of production, as a result of better use of production capacity, is reflected in a reduction of fixed costs.

Variable costs are those costs that change under the influence of the physical volume of production.

\section{PRESENTATION OF RESEARCH RESULTS}

\subsection{Presentation of the business}

Sustainability is a way of economic development if it is consciously implemented by society. This paper identifies the application of sustainability at the level of a company through an innovative, successful vision. To begin with, a brief approach to the term sustainability is made, to be considered several considerations regarding the cost of production and the calculation of costs, these are mechanisms of implementation of the Six Sigma method, integrating these notions in the case study of a successful company from Romania.

The research carried out in this chapter aims to reach two important conclusions regarding the sustainability of a company: the sustainability applied properly produces long-term positive effects on the community and the sustainability creates a healthy economic growth and development within a company.

Regarding the term of sustainability according to the World Commission for Development and Environment, sustainable development is development that meets the needs of the present, without compromising the ability of future generations to meet their own needs.

As a result of global population growth, meat production is increasing every year. One of the reasons for the increase in meat production is the liberalization of trade and the globalization of food systems. The second reason could be the nutritional needs and eating habits adopted by eating foods with a higher content of animal protein. Last but not least, consumers around the world accept these products because of their cultural perception.

Worldwide total meat production is estimated at around 320 million tons in 2016, with growth in America and Europe and a slight decrease in China and Australia. With the exception of China, world meat production is expected to grow by almost $2 \%$ per year. According to the OECD, beef is expected to have the highest growth in production, with marginal increases for sheep meat and a slight decrease for pork.

Regarding pork consume in Europe, according to the OCED, the average is about 32 $\mathrm{kg} / \mathrm{resident}$, being ranked first in the world. Regarding chicken meat the average European consumption is $24 \mathrm{~kg} /$ resident.

At the national level according to INS data meat consumption is raising, which is a benefic element for the companies in the meat processing sector. 
The company analyzed in this project understood these elements very well, so that the market segment to which it is addressed is constantly growing. From an economic point of view, the company presented a good situation, but considering the competitive situation on the market, measures had to be taken to ensure a healthy future.

The complexity of the economic activity characteristic of today's society has imposed, both theoretically and practically, the outline, definition and differentiation of the production process from the management process. The production process aims at the transformation of material goods by means of means, using a certain technology, organized within a system. In order to coordinate the economic process, information needs to be collected, processed and transmitted to the management, by means of means that make up the information system. From the point of view of the input-output system, the production is the process of transforming the elements of inputs into elements of outputs specific to the set objectives.

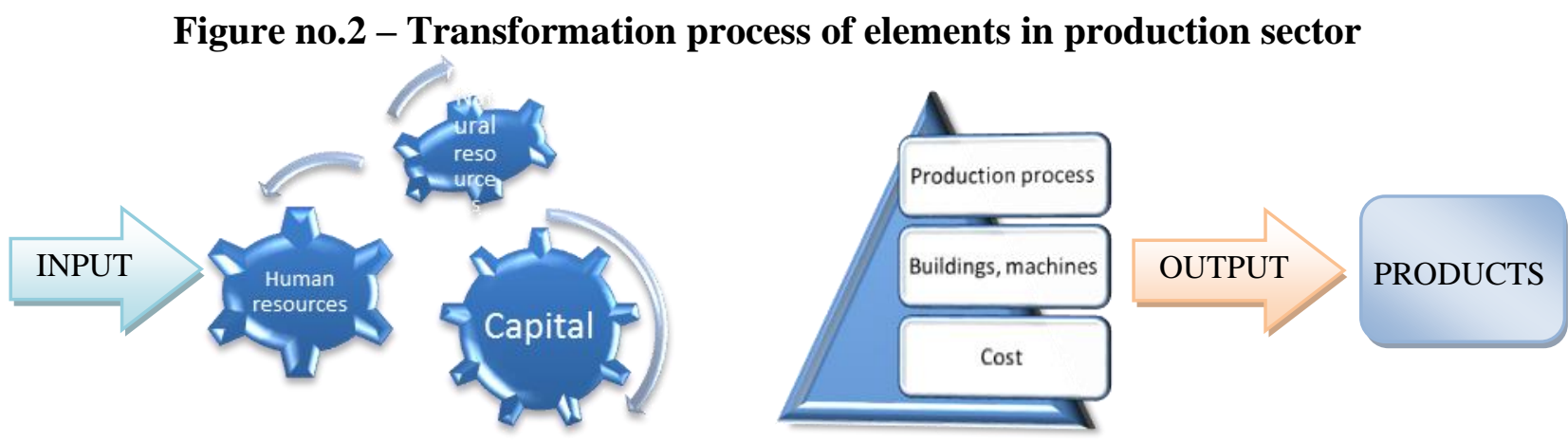

Source: Authors 'projection

Wherever production activities take place, there are certainly costs. An expansion beyond certain limits can push a firm on the brink of bankruptcy, as its revenues grow at a lower rate than its costs.

Almost always there is a need for a building, an element of the fixed capital area, also from this structure there are also industrial plants and special equipment that will ensure the production process.

The production process generates exiting elements in the form of fabricated products, executed works or services provided. The specification of the output elements determines and must usually constitute the starting point in organizing the production process and related to it in ensuring the input elements.

The management must exert a permanent control over the production process in order to obtain the manufactured products or the works executed with minimum costs and a high quality level. Thus, applying the Six Sigma method in such an economic environment can bring results beyond the expectations of the company's management.

As the system of inputs and outputs is the basis of the production process, the management has the task that through the decisions taken to ensure the full coordination of the elements of the system in order to achieve the set objectives. Thus the definition would be the first element of the Six Sigma method stage in which the management is aware of and identifies the problems of the society. Often there are situations where these issues are related to costs.

Most times a company minimizes its production costs. This premise is valid not only for the companies that operate in the competitive markets, but also for the monopolistic companies. 


\section{sciendo \\ ACTA MARISIENSIS, SERIA OECONOMICA \\ Online:ISSN 2668-3989, ISSN L 2668-3148 \\ Print:ISSN 2668-3148, ISSN L 2668-3148}

A company will try to achieve the desired result with the lowest possible costs so that, from the maximum income obtained, it will take the necessary amounts for other objectives.

Thus, cost calculation is an instrument of management, which made it integrated into management techniques, being known in the specialized literature under the name of management by cost. Cost calculation is transformed into a management tool capable of meeting all the demands of the modern management of the company (Olariu, 1975).

The company analyzed in the case study has a market share of $17-18 \%$. The entrepreneur who founded this company was not the first to enter the market, this being the fourth company established after three of them went bankrupt. After opening a grocery store, which has been in operation for several years, the manufacturer has decided to make its way to the production area through a sausage factory. A first argument for the consolidation of the bus in this segment of activity was the fiscal facilities granted by the state. Another equally important argument was the demand on the Romanian market for these foods.

The business has resisted during the turbulent period since the mid-1990s and the producer has now paid more than 2,000 employees every month, who work in his factory, either in his construction company or in the retail network operated.

The crisis that rocked the Romanian economy at the end of 2008 also affected the company's activity. The government's decision to increase the VAT from $19 \%$ to $24 \%$ cut the appetite for consumption of Romanians, and the producer saw that its business decreased in three years in $2008-2010$ by $15 \%$. As a result, the entrepreneur shifted to foreign markets. The entrepreneur lost several times everything, but managed to find the strength to take it again from scratch, so that now he is in the chair of a business of over 100 million euros a year.

Thus, in 2012, we went to an evaluation of the company, precisely to decide the future activity of the company.

SWOT Analysis

Strong points:

- Recognized brand;

- High variety of products;

- The society offers products at good price and high quality;

- Qualified staff;

- The use of high end machines;

- Experience in that domain.

Weak points:

- Impossibility of placing online orders;

- Neutralizing the production lines at the maximum capacity;

- Lack of a strategy of reducing costs constantly increasing.

Opportunities:

- Attracting new distributors for expansion;

- The recovery of the economy and the growth of the market growth rate;

- Increased exports;

- Making products that satisfy every tastes of customer, no matter what his age/income are.

Threats: 
- Increasing the prices of raw materials;

- The competitive prices by the competition;

- Increasing costs with supply;

- Decreasing the buying power of customers.

After the analysis is done it was deduced a very important thing, the company is missing the most important element: the sustainability.

\subsection{Analysis of the correlation between the Six Sigma method and the performance of a company}

The capacity of a company of obtaining sustainability depends for the most part on its ambient and social sensibility. In other words it need to become ecocentric first, then focus on sustainability. All these elements demand time and effort. So the management of the company understood this aspect as a result of the project, despite the special financial efforts, was carried out according to the plan. By applying Six Sigma and Lean Six Sigma methods, it leads to a successful or strategic involvement in caring for a past beyond compliance and efficiency, precisely to avoid risks and minimize costs. Thus, the strategy can be created a sustainability to be able to the fast strategy.

Sustainable creation also involves collaboration with the outside world. The management of the company has adapted perfectly to this principle so that as we will see in the following pages the collaboration with other economic agents has laid the groundwork for innovative systems for Romania.

The cost calculation method used in the studied company is the standard-cost method. This helps to provide information regarding the production costs and at the same time to develop the forecasting side of the management accounting. The standard-cost method promotes the idea of calculating average production costs in advance. These are considered real costs. This method has a number of advantages in terms of efficient production management.

The point from which the company analyzed in this paper starts is the problem of the costs that were constantly increasing. The company understood that building a future based on sustainability is more important than profit orientation.

Firms can transform the reputation from an intangible asset into a tangible one, integrating sustainability risk management. Its integration can contribute to a sustainable competitive advantage, optimizing the cost of risk management. Standard costs are production costs established in advance under the conditions imposed by technological processes.

Considering that the basic function of the standard costs is that of standard of measurement and comparison of the actual costs, thus exercising a systematic control over them, the use of the standard-cost method implies: elaboration of the standard cost calculations for the products to be manufactured; calculating, tracking and controlling deviations from standard costs; cost tracking according to some requirements specific to this method.

In the second stage of the Six Sigma method, the measurement one identified the data that indicated an imminent problem in the proper functioning of the economic activity of the company. As can be seen in table no.1 below, two of the economic indicators, the rate of profitability and the rate of profit, present a rather delicate situation for the company. The two indicators have a negative situation in 2012 and 2014 respectively.

Regarding the situation of the current assets, their value is significantly higher than the fixed assets, and regarding their evolution between 2012 and 2016 the data show that the value 
of the current assets has doubled in 2016 compared to 2015. The biggest influence on the current assets has had debts, worth about 209724602 lei.

Figure no.3 - Situation of current and fixed assets (2012-2016)

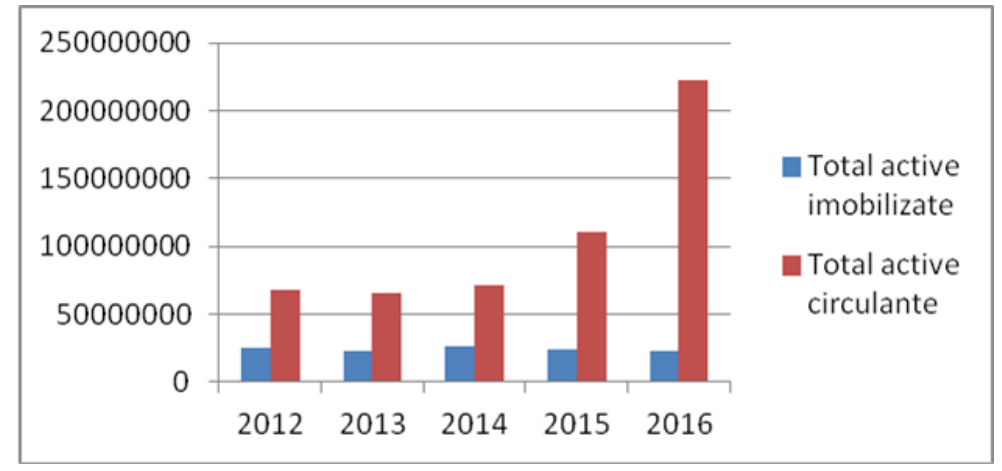

Source: http://doingbusiness.ro/financiar/raport/956874/

Analyzing the turnover of the company we observe a constant growth from $280,193,191$ lei in 2012, to 606288260 lei in 2016, with a net profit in 2016 of 4,276,873 lei. Regarding the labor productivity calculated according to the table in the annex it can be deduced that:

$$
\mathrm{W}=\frac{Q P}{L} \text {, from where: } \mathrm{W}_{2012}=\frac{280193191}{667}=420080 \text { lei } / \text { pers. }
$$

The data obtained are summarized in Table 1.

Also to find out the rate of return and the rate of profit was used the following formula:

$$
\mathrm{R}_{\mathrm{PrK}}=\frac{P r b}{K} * 100, \quad \mathrm{R}_{\mathrm{PrQP}}=\frac{P r}{Q P} * 100 .
$$

After the calculations made the main indicators are presented as follows:

Table no. 1 - Own calculations based on the source data

\begin{tabular}{|c|c|c|c|c|c|c|}
\hline Year & $\mathbf{2 0 1 2}$ & $\mathbf{2 0 1 3}$ & $\mathbf{2 0 1 4}$ & $\mathbf{2 0 1 5}$ & $\mathbf{2 0 1 6}$ & $\mathbf{2 0 1 7}$ \\
\hline Productivity & 420080 & 513680 & 478220 & 526095 & 619927 & 682087 \\
\hline Rentability rate & $\mathbf{- 1 0 . 3 3}$ & 14.11 & $\mathbf{- 8 5 . 9 2}$ & 65.71 & 202.24 & 190.09 \\
\hline Profit rate & $\mathbf{- 3 . 0 9 9}$ & 0.630 & $\mathbf{- 0 . 3 1 1}$ & 1.392 & 0.832 & 0.830 \\
\hline
\end{tabular}

Source: http://doingbusiness.ro/financiar/raport/956874/

In 2013 we can see an increase in labor productivity by $22 \%$ compared to 2012, which contributed to an increase in the rate of return by $14 \%$ in 2013. In 2014, the productivity of work within the company decreased by about $7 \%$ compared to year 2013 which led to a decrease in the rate of profit calculated at the turnover of $-0.3 \%$ for 2014 and a decrease in the rate of return to $85.72 \%$. In 2015 and 2016, labor productivity continued to increase by $10 \%$ and $30 \%$, respectively, compared to 2014, reflecting an increase in the rate of return of $65 \%$ in 2015 and $202 \%$ in 2016. 
Any manufacturer will try to get a lower cost for its product, formed on the basis of demand and supply. In this way the manufacturer will enter the market if its cost is lower than the price, the lower the cost than the new price, the higher its profit. That is why any manufacturer will try to reduce its cost (Vâlceanu et al., 2005).

Figure no. 4 - Evolution of the turnover in the company (2012-2016)

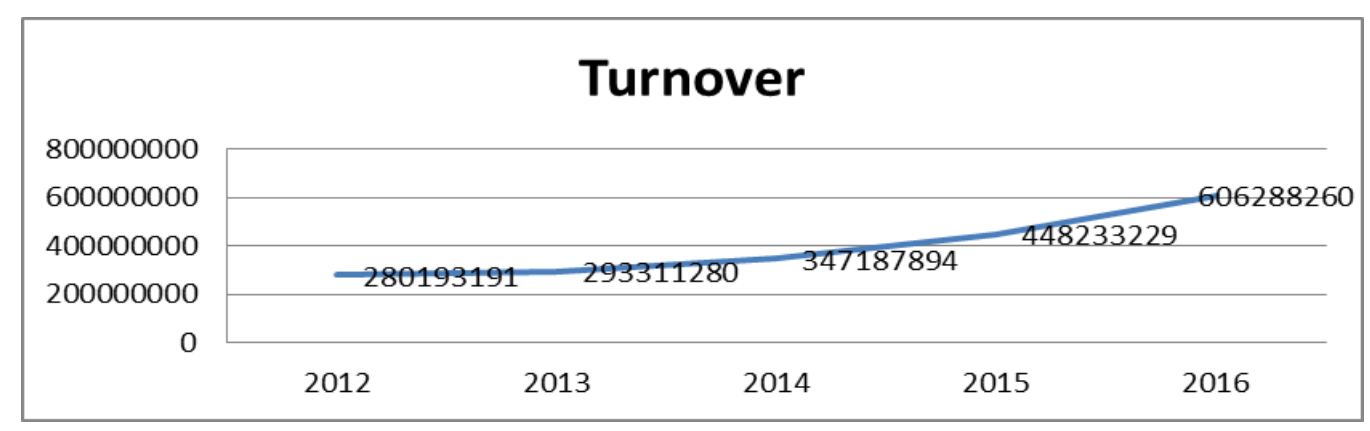

Source: http://doingbusiness.ro/financiar/raport/956874/

Figure no. 5 - Statement of profit made within the company in the period 2012-2016

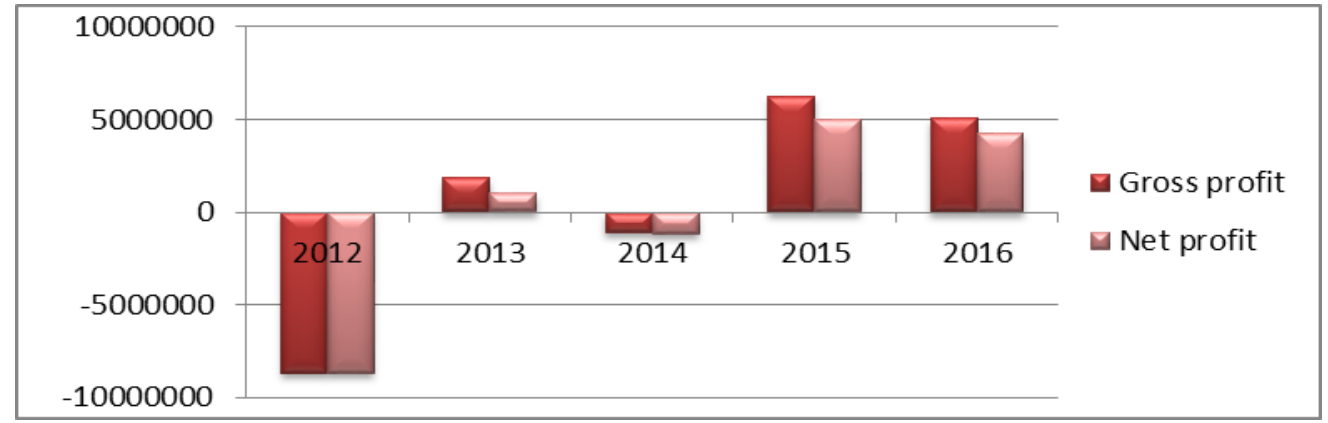

Source: http://doingbusiness.ro/financiar/raport/956874/

The profit of the company over the last 5 years has fluctuated quite a lot as a result of the increased costs following the investments made.

It can be seen in the table how the income situation is quite close in value, talking about the expenditure situation.

To perform this analysis we used the indicator "Cost per 1000 lei turnover". This indicator has been used in Romania since 1961 and the calculation relation is expressed:

$$
\mathrm{I}=\frac{C T}{Q P} * 1000 \text {. }
$$

This report provides information on the effectiveness of the expense ratio - results, from its value equal to 1000 , one begins the assessment of the efficiency of the activity carried out. If the value of this indicator is less than 1000 (I <1000) it is a normal situation and it is worth noting that less than 1000 lei is spent to obtain 1000 lei at the turnover; if $I>1000$, it is an abnormal situation that shows that to obtain 1000 lei production, more than 1000 lei is spent, in which case the economic agent registers losses. Table 2 shows how indicator I is higher in 2012 and 2014, which reflects losses over the two years, a situation not exactly healthy for the company. 
Figure no. 6 - Income and expenditure graph (2012-2016)

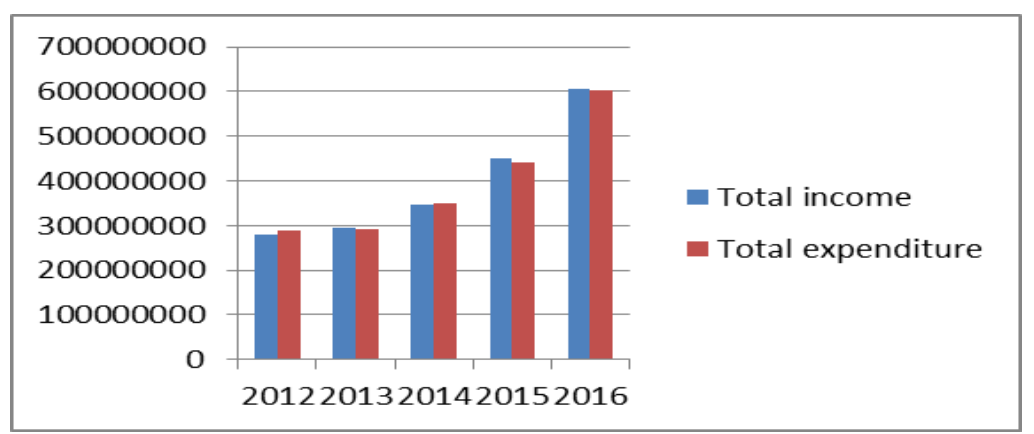

Source: http://doingbusiness.ro/financiar/raport/956874/

The synthetic model presented above offers the possibility of applying marginalism in the research of this indicator (Gheorghiu, 2004).

The following data is obtained by combining the data in the table in the annex:

Table no. 2 - Own calculations based on the figures from the source (2012-2017)

\begin{tabular}{|c|c|c|c|c|c|c|}
\hline AN & 2012 & 2013 & 2014 & 2015 & 2016 & 2017 \\
\hline TOTAL EXPENDITURE & $\mathbf{2 8 9 6 6 6 2 6 7}$ & $\mathbf{2 9 2 4 8 2 1 4 0}$ & $\mathbf{3 4 8 9 1 0 1 0 9}$ & $\mathbf{4 4 2 7 3 3 6 3 7}$ & $\mathbf{6 0 1 5 5 6 4 3 1}$ & $\mathbf{7 5 6 7 5 3 2 1 8}$ \\
\hline TURNOVER & $\mathbf{2 8 0 1 9 3 1 9 1}$ & $\mathbf{2 9 3 3 1 1 2 8 0}$ & $\mathbf{3 4 7 1 8 7 8 9 4}$ & $\mathbf{4 4 8 2 3 3 2 2 9}$ & $\mathbf{6 0 6 2 8 8 2 6 0}$ & $\mathbf{7 6 0 5 2 6 7 2 7}$ \\
\hline$\Delta$ CT\% & 1.24 & $\mathbf{0 . 9 7}$ & 19.29 & $\mathbf{2 6 . 8 9}$ & 35.87 & 25.80 \\
\hline$\Delta$ QP\% & -3.07 & 4.68 & 18.37 & 29.10 & 35.26 & 25.44 \\
\hline I & $1,033.81$ & 997.17 & $1,004.96$ & $\mathbf{9 8 7 . 7 3}$ & 992.20 & 995.04 \\
\hline EERFP & 0.96 & 1 & 0.99 & 1.01 & 1 & 1.00 \\
\hline
\end{tabular}

Source: http://doingbusiness.ro/financiar/raport/956874/

From this table we can deduce that in 2012 the total costs increased at a rate higher than the growth of the turnover, which was not a healthy element from an economic point of view for the company, the same situation being in 2014 where the total costs exceeded the rate of increase of the turnover.

The indicator of economic efficiency regarding the yield of the production factors used in the above table justifies the unfavorable economic situation in 2012 and 2014 respectively.

Adopting a long-term recovery strategy regarding the reduction of production costs, a situation analyzed by the Six Sigma method, the management of the company laid the foundations of investments that would change the economic situation in the coming years. This is the fourth step of the Six Sigma method, namely improvement.

It was practically the moment when the company began to rethink the basic principles on which the business was founded. At that time, the company understood that sustainability is not a model of capital growth but is a successful strategy for the future (Duckworth et al., 2016). If 
until then the company was focused on supplying products that met the customers' demands through competitive prices, once the long-term strategy was rethought, a new orientation was laid, with a dramatic change to the mechanisms that were not sustainable. The sustainability that was called into question should also encourage the use of resources in a responsible manner.

Thus, in 2013, the first Romanian station for the production of renewable energy in cogeneration, based on biogas, appeared. This investment made in collaboration with different foreign partners was inaugurated for the first time in Romania, the station having a capacity of $1 \mathrm{MW} / \mathrm{h}$ electric and 1.2MW / h thermal that processes daily an amount of 49 tons organic substrate, the entire value of the project raising- is at an investment of about 5,000,000 euros.

The company has managed to effectively combine the three parts of sustainability:

\section{Figure no.7 - The main elements of sustainability}

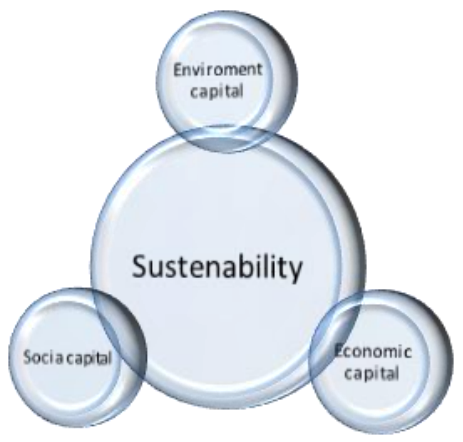

Source: Authors`projection

Regarding the ratio between the fixed costs and the variable costs, the highest weight in the period 2012-2014 had the fixed costs. Thus, most of the investment was realized in the form of machinery, building, equipment and materials necessary for the implementation of the renewable energy production plant. The share of the variable costs was substantially lower in the total costs and due to the fact that the main raw material used in the plant came from the slaughterhouses of the parent company, this being in the form of the remaining residues and which could not be processed in the production activity. Thus, if until then only $70 \%$ of the mass of an animal could be used in the production process, after the construction of the plant the remaining $30 \%$ of the animal would go as fuel of the plant. Thus, part of the working capital used was reduced.

The desire to develop a sustainable business was also fueled by the growing trend of the profile market in this segment. Thus, if we were to analyze the most recent data at national level given to the advertising by the NIS, it can be observed that the indicator regarding the average consumption of meat per inhabitant is constantly increasing.

The implementation of the project, unique in Romania so far, began in June 2012 with the purpose of producing renewable energy (electric and thermal), in cogeneration, through the use of organic substrate (plant and, subsequently, organic waste) in the site area. The novelty of the project is the supply to a partner of the thermal energy produced by the cogeneration plant, the production of electricity in the band, the predictable supply (over 8000 operating hours / year), as well as the possibility of storing the energy (biogas). 


\section{sciendo}

ACTA MARISIENSIS, SERIA OECONOMICA

Online:ISSN 2668-3989, ISSN L 2668-3148

Print:ISSN 2668-3148, ISSN L 2668-3148

Starting from the premise that exceptional companies must not only create value, but also accumulate it through profits, the company has tried to obtain a higher value of the profit rate by increasing the turnover. Exceptional firms have a fairly large profitability formula that can be summarized in the form of: revenues before costs.

The basic principle that was at the construction of this project, it could be said that there was rather a compromise regarding obtaining a higher profitability, having to choose between increasing the income and lowering the costs, but we will see below that the project is in fact it was based on another strategy, through which it was pursued the implementation of sustainability. It seems that the company's strategy was to increase revenues, even at the cost of higher costs.

The advantage in profitability is rarely supported by costs, but is often based on disproportionately higher incomes.

If by 2012 the highest share in the cost of the product within the company was held by the variable cost, after the construction of the plant this variable cost was significantly reduced which led the company to one of the leading places at national level. The profile market in Romania is a monopolistic type, the company understood that a new strategy must be adopted on the market, as a result it managed to bring a competitive price on the market by applying the strategy of global domination through costs.

The project is a sustainable one. It is the basis of the development of three priority areas in Romania: energy, agriculture and environmental protection, and the biogas-based cogeneration plant is suitable for any industrial consumer who uses thermal energy (hot water, technological steam, hot air).

The partnership consists of harnessing the thermal energy produced in cogeneration, while the factory benefits from lowering the cost of producing the thermal energy, as well as the efficient management of waste resulting from meat processing.

Thanks to the new technologies introduced exclusively in Romania and to the innovations at the recipe level, Romanians can now enjoy gluten-free, starch-free, MDM-free, soy-free, synthetic dyes or added sodium monoglutamat.

Due to the research of the technologies and values applied at the recipe level according to the latest trends to provide the local and global level, it may have more meat, more essential amino acids and be able to use higher foods.

Due to investments in technology and recipe enhancement according to the latest food trends locally and globally, the products now contain more meat, more essential amino acids and have greater food security.

\section{CONCLUSIONS}

Too few investors in the Romanian business environment have thought of a sustainable business development strategy and too few investors are implementing Six Sigma and Lean Six Sigma methods in their business. In the production process it is essential to reduce costs and maximize the resources, precisely the basic idea on which the two methods are based. A sustainable business strategy improves performance by reducing business costs while 
simultaneously combining value creation with maximizing profit for stakeholders. Even if the purpose of capitalism can be to maximize profit, the overall objective of an economic system should be to provide value for society, not just the accumulation of capital.

The globalized society is characterized by a continuous increase in the demand for energy, both due to the rapid growth of the population and the standard of living.

Every company in its activity uses a volume of resources. This operation must be transformed into a sustainable activity, it must be regarded as an opportunity of the business environment to make sustainable decisions.

Biomass resources can be considered as important raw materials for producing high value-added products (Plenert, 2018).

The cost of production also plays an important role in substantiating decisions at the enterprise level. For this one must know precisely the expenses that compose it.

Although Milton Friedman's classic approach to business development considers profit maximization to be core, I believe that the company should not be strictly profit oriented but on developing the capabilities to provide management capable of providing future generations with a sustainable development model; a responsible use of resources so that the operation does not create environmental concerns that could harm the balance of the environment. In other words, this is also the basic idea of sustainability, to obtain economic efficiency, social equity and preservation of the environment.

The positioning of a company defines how it generates value for customers, compared to other companies. The Six Sigma method and the Lean Six Sigma method facilitate this process and are the most suitable elements to implement a revitalization of the way the economic activity unfolds. The profitability rate of a company describes how it accumulates value for itself, compared to others. Just as there is a pattern for how exceptional companies manage to generate value, there is a pattern for how they accumulate value. All of these elements combined with efficient sustainability ensure business success. The company presented in the case study understood the importance of sustainability in the economic activity and the need to apply the two methods in a period that could be decisive for the good performance of the activity.

Accurate knowledge of costs has an effect on managerial decisions. The company has implemented several measures to reduce costs, such as: increasing labor productivity, modernizing with new and high performance machines, introducing innovative production systems on the market, from which customers will have to win. Through the innovation that the company has succeeded in bringing to the market, it has created a sustainable business environment, improving both the economic environment within the company and the social environment in which it operates.

The company is a brand that believes in a future where innovation and technology are at the service of human health, and sausages are natural, tasty and nutritious foods.

The statistics show the company as the strongest, best known and best-selling sausage brand in Romania, according to market surveys.

The most important elements that underpin the success of this company are the ambition, the devotion and the respect put in the client's service.

The company is dedicated to offering the consumer what he wants, depending on his taste and mood, producing a balanced range of healthy, fresh, regional and international products, a varied range of classic, vegetable or children's sausages. The company believes in a future where all people will eat healthy, and sausages will be natural, healthy and nutritious foods. 


\section{sciendo \\ ACTA MARISIENSIS, SERIA OECONOMICA \\ Online:ISSN 2668-3989, ISSN L 2668-3148 \\ Print:ISSN 2668-3148, ISSN L 2668-3148}

The company succeeded in introducing an innovation in the market and at the same time applying a new strategy that proved to be a successful one. Thus, the company reduced the share of variable costs in total costs using the animal product by $100 \%$, which is unique on the domestic market. From the analysis carried out it can be observed that in the period 2012-2014 all the analyzed indicators indicate a precarious situation of the company from an economic point of view, as a result of the investments made, but in the long term the opportunity cost was favorable to the company. Although the initiative was not initially supported by the entire board of the company, it was a real success, the data presented being very favorable.

What was once considered a waste, eventually became an asset and was appropriately capitalized through the implementation of the Six Sigma and Lean Six Sigma methods.

Among the strengths of the company's sustainability would be the significant improvement of the performances in the field of environmental protection, the functional management regarding the value chain, the acceptance of the ideas of those involved in the opportunities offered by the company, etc. The presented company creates a balanced environmental, social and economic sustainability (Truscott, 2003).

In the production sector, the Six Sigma mechanism has a fairly precise delimitation: measurements, complex projects (DMAIC), statistics, etc. But in the service sector the situation is different because people do not behave like cars, in the sense that it is not enough to press a button to repair the situation.

The two Lean and Six Sigma methods must be a perfect combination, in which customer opinion is more important than a graph. Efficiency is paramount, but in services these methods are applied differently to production, although when it comes to quality and sustainability, they are equally important for both sectors.

In services the degree of customer satisfaction are capital elements, while in production the emphasis is placed on statistical calculations. The interaction with the customer supports a natural variation, given by the human factor. If the optimization can be done in a relatively short time, the improvement time in production varies, on average 6-9 months.

By practicing the Six Sigma and Lean Six Sigma services in the sector, different skills can be acquired: negotiating and influencing decision-makers, the ability to collect and use data appropriately, developing leadership skills, understanding the human capabilities needed for the project, understanding how to use quality improvement tools, etc.

Through the use of these methods different relationships can be developed within organizations, identifying opportunities.

As the company progresses to the higher levels of sustainability maturity, its influence becomes more visible in comparison with the other companies in the field. Organic products have a higher value and more and more customers prefer companies that are operating in a sustainable way. As the results analyzed in this paper indicate, the company has managed to achieve better results with the integration of sustainability in its strategy. Sustainability rewards those who own and use it. 


\section{Bibliography:}

Dan M. (2012). Lean Six Sigma între teorie și practică, Management și Calitate, Revista T\&T Tehnică și Tehnologie, Tehnic Media. ISSN 1453-8423, https://www.ttonline.ro/revista/management-calitate/lean-six-sigma-intre-teorie-si-practica

Nelson B., Sproull B. (2016). The Critical Methodology for Theory of Constraints, Lean, and Six Sigma, ed. CRC Press, NW,. ISBN 13: 978-1-4987-4605-2

Truscott W. (2003), Six Sigma: Continual Improvement for Businesses, ed. Butterworth Heinemann, USA. ISBN 0750657650

Bhale N. P. (2017), Six Sigma in Service: Insights from Hospitality Industry, International Journal of Advance Research in Science and Engineering, Vol. No. 6. ISSN 2319-8354

Gygi C., DeCarlo N. (2005), Six Sigma for Dummies, ed. Wiley Publishing, NJ. ISBN 0-76456798-5

Tetteh E.G., Uzochukwu B.M. (2015). Lean Six Sigma Approaches in Manufacturing, Services and Production, ed. IGI Global, ISBN 978-1-4666-7320-5

Kesterson R. K. (2018). The Intersection of Change Management and Lean Six Sigma, ed. CRC Press, USA. ISBN 13: 978-1-1382-1702-7

Bloom D. (2016). The Field Guide to Achieving HR Excellence through Six Sigma, ed. CRC Press, NW,. ISBN 13: 978-1-4987-5850-5

Caroll C. T. (2013). Six Sigma for Powerful Improvement, ed. CRC Press, NW. ISBN 13: 978-14665-6470-1

Olariu C. (1975). Conducerea întreprinderii prin costuri, ed. Facla, Bucureşti.

Wei Z., Xuru D. (2016), Lean Six Sigma and Statistical Tools for Engineers and Engineering Managers, ed. Momentum Press, New York, 2016. ISBN 13: 978-1-60650-492-5

Vâlceanu Gh., Robu, V., Georgescu N. (2005) Analiză economico-financiară, Editura Economică, București, p.188-197.

Gheorghiu Al. (2004), Analiză economico-financiară la nivel microeconomic, Editura Economică, Bucureşti, 2004, p.143-146.

Duckworth H. A., Hoffmeier A. (2016), A Six Sigma Approach to Sustainability, ed. CRC Press, NW. ISBN 13: 978-1-4987-2086-1

Plenert G. (2018). Strategic Excellence in the Architecture, Engineering and Construction Industries, ed. Routledge, USA. ISBN 13: 978-1-138-47885-5

https://doingbusiness.ro/financiar/raport/956874/

https://www.sixsigmaonline.org/six-sigma-training-certification-information/category/six-sigmaspecialized-by-industry/

https://www.sixsigmaonline.org/six-sigma-training-certification-information/the-world-ofhospitality-and-six-sigma/

https://www.henryharvin.com/blog/27/5-benefits-of-six-sigma-for-hospitality-managementprofessionals

https://www.pearsonhighered.com/hmods/modules/process-revenue-management/six-sigma-andits-application/index.html 